\title{
Influencing Factors of Taxpayers' Tax Compliance in the Perspective of Government Governance
}

\author{
Zexin Shi* \\ Zhongnan University of Economics and Law, Wuhan City, China \\ *Corresponding author: Zexin Shi, 1692226806@qq.com
}

\begin{abstract}
At present, government governance reflects that the new public management plays an irreplaceable role in promoting the social participation of democratic individuals, stimulating the vitality of the society, as well as improving the equal consultation between citizens and governments under the guidance of the governance spirit. Especially in the process of transformation of the industrial society, significant changes have taken place in government governance modes. The government plays important roles in the democratic society to form clear theoretical frameworks in view of their understanding towards the modernization of government governance. With significant development of information technology, existing modes of social and economic developments had transformed in addition to profound social changes. These developments would affect the research on government governance. In the perspective of government governance, it is of great significance to explore its role in the influence towards tax compliance especially under the current system and mechanism to create an excellent tax compliance spirit. From existing research, the main aspects used in measuring government governance are the openness of government affairs, social justice, and individuals' understanding of the tax law. With existing research, 201 survey questionnaires of the subjects, validity analysis, descriptive statistics analysis, correlation analysis, regression analysis, and other methods, this study made bold assumptions on the relationship between government governance and tax compliance. The conclusion in which government governance, measured in terms of government affairs, degree of social justice, and personal understanding of the tax law would influence taxpayers' tax compliance in terms of their consciousness towards tax compliance. At present time, the study of government governance and taxpayers' tax compliance has practical significance and application value. This study would provide an opportunity for citizens to have a preliminary understanding of overall tax compliance and maintain the spirit of tax compliance from an individual's subjective consciousness in addition to providing suggestions to improve government governance for promoting tax compliance.
\end{abstract}

Keywords: Government governance; Tax compliance; Taxpayer

Publication date: June 2021; Online publication: June 30, 2021

\section{Introduction}

Government governance is a specific range between various functional departments in which the multilevels public sector and public organizations coordinate with one other. It involves all sorts of interactions between the government and public regarding social and public and affairs related interests for equal participation and adjustments. In regard to the research on government governance of government management, government governance reflects the practical significance of the new public management in promoting the participation of civil society, shaping citizens' own pursuit, stimulating the overall vitality of the society, improving the results of equal consultations between citizens and governments, and safeguarding the fundamental interests of the people.

At present time, existing research on the correlation between government governance and tax compliance of taxpayers have practical significance and application value. Firstly, it enables citizens to 
have a preliminary understanding of tax compliance while consciously maintaining their personal subjective will in regard to tax compliance. Second, under proper guidance of the government governance system, citizens' tax compliance would be improved and significantly enhanced. Finally, the epitome of the public sector governance ability in terms of tax is manifested through the development of the citizens' social identity to a certain level in their subjective will on tax compliance.

Tax compliance refers to the awareness of taxpayers to comply with tax laws and regulations as well as various tax policies. Government departments should determine and calculate the various taxes to be paid while taxpayers should consciously obey the guidance from tax authorities. In addition to that, tax law enforcement personnel should promote administrative management behaviors in accordance with legal norms. In simpler terms, tax compliance necessitates taxpayers to fulfill their obligations to pay taxes according to the tax law with three indispensable requirements which are timely application, accurate payments, and on time payments.

\section{Models of Government Governance Influencing Taxpayers' Tax Compliance}

The proposed models are based on the theoretical basis of tax compliance. The research models are shown in Figure 1. In this study, the independent variable used was governance while the dependent variable was tax compliance. The government governance was measured in three aspects which were the degree of openness, personal understanding of the tax law, and the measure of social justice whereby the latter is the Engel's coefficient among the three.

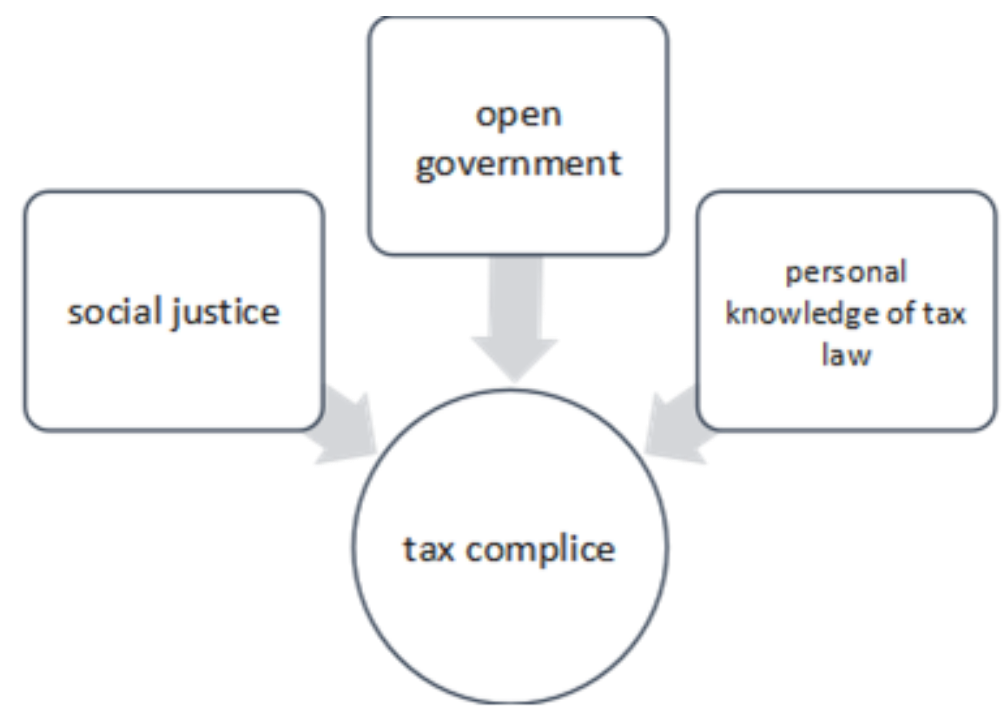

Figure 1. Research models

First of all, in the public governance theory, the study of both government governance and taxpayers' compliance which explores relevant variables mainly focuses on the causal relationship between the influence and compliance. In this study, the government governance is an explanatory variable which acts as the leading role for the governance of other parties in promoting compliant behaviors.

Secondly, in the governance research of taxpayers' subjective will behavior, it is mainly based on the subjective will of taxpayers to comply with taxes. In order to strengthen the taxpayers' will of tax compliance to achieve a standard tax compliance, it is necessary to reinforce the governance of the government, promote the construction of the government's governance system capacity, safeguard the rights and obligations of normal taxpayers.

Finally, in line with the stakeholder theory, stakeholders should actively comply to the relevant tax 
guidelines so that the interests of the relevant parties are reasonable. In this study, the government governance relates to the public governance behavior in which compliance and governance are important factors. Therefore, as long as the governance is rational and adopts reasonable means, excellent governance results would eventually be guaranteed.

\section{Tax Compliance Theory}

The theory of tax compliance usually refers to the degree of taxpayers' willingness to comply with the tax law under the control of subjective psychological attitude. Tax compliance simply means that taxpayers comply to tax laws. Tax evasion is a legal concept however, tax compliance does not only have meaning in regard to the law, but it also refers to the citizens' moral implications.

Tax evasion refers to the subjective behavior of taxpayers which denotes an individual's intention to violate the current tax law system in order to avoid his or her obligation in paying taxes. Broadly speaking, it is a tax fraud. Tax evasion has many forms which includes the failure of taxpayers to fulfill their tax obligations stipulated in the tax law. Illegal conducts of tax evasion would include subjective negligence and objective errors. International tax evasion has been rooted especially within organizations, therefore economic co-operation often uses this kind of concept in forming international consensus.

Tax compliance which is the taxpayers' willingness to fulfill their obligations to pay taxes according to the requirements of the tax law is the fundamental concept in accordance with the tax law. The national academy of sciences defined tax compliance as first, the taxpayers' tax returns according to the existing tax laws and relevant provisions of the tax law, then, the official written proclamation in regard to the parliament's decision. Subsequently, the returns should be filled in time, accurately calculated, and finally, taxes are paid.

\section{Analysis on the Influence of Government Governance on Taxpayers' Tax Compliance}

To investigate the influencing factors of government governance, the governance indicators based on the book, Indicators of Government Governance, which was edited by American scholar, Stephens and published by Tsinghua University Press on October 1, 2007, were chosen. In order to ensure the reliability and operability of the results from the survey questionnaires, the method commonly used in psychological survey was adopted whereby demographic statistics were used as controlled variables.

Correlation analysis is usually used to test and measure whether the variables used have a correlation with one other. In this study, Pearson's correlation analysis was used to test and analyze the correlation between the two variables and to verify the degree of correlation by observing the correlation coefficient, $\mathrm{R}$. If $|\mathrm{R}|$ was less than 0.3 , it would demarcate a weak correlation between the variables while if $|\mathrm{R}|$ was between $0.3-0.5$, it would indicate that the variables had low correlation. If $|\mathrm{R}|$ was between $0.5-0.8$, it would indicate moderate correlation between the variables and if $|R|$ was greater than 0.8 , it would indicate a high correlation between the variables.

The correlation coefficients among the variables are shown in Table 2 and the following conclusions were drawn:

The openness of government affairs was significantly positively correlated with tax compliance $(\mathrm{R}=$ $0.706, \mathrm{P}<0.000)$.

Social justice was positively correlated with tax compliance $(\mathrm{R}=-0.402, \mathrm{P}<0.000)$.

Personal understanding of tax law was significantly positively correlated with tax compliance $(\mathrm{R}=$ $0.662, \mathrm{P}<0.000)$.

Hence, from the above correlation analysis, it can be concluded that there is a significant positive correlation between government governance and the tax compliance of taxpayers. 
Table 2. Correlation analysis of major variables $(\mathrm{N}=201)$

\begin{tabular}{|c|c|c|c|c|c|}
\hline & & $\begin{array}{l}\text { Willingness to cooperate } \\
\text { with the tax authorities in } \\
\text { complying with tax laws } \\
\text { (Likert five-point scale) }\end{array}$ & $\begin{array}{l}\text { Openness } \\
\text { of the } \\
\text { government }\end{array}$ & $\begin{array}{c}\text { Social justice } \\
\text { (Engel's } \\
\text { coefficient) }\end{array}$ & $\begin{array}{l}\text { Personal } \\
\text { understanding } \\
\text { of the tax law }\end{array}$ \\
\hline \multirow{5}{*}{$\begin{array}{l}\text { Willingness to } \\
\text { cooperate with the } \\
\text { tax authorities in } \\
\text { complying with } \\
\text { tax laws (Likert } \\
\text { five-point scale) }\end{array}$} & Pearson correlation & 1 & $.706 * *$ & $-.402 * *$ & $.662 * *$ \\
\hline & $\begin{array}{c}\text { Significance } \\
\text { (bilateral) }\end{array}$ & & .000 & .000 & .000 \\
\hline & $\begin{array}{l}\text { Sum of squared and } \\
\text { cross product }\end{array}$ & 327.433 & 219.284 & -150.015 & 248.776 \\
\hline & covariance & 1.637 & 1.096 & -.750 & 1.244 \\
\hline & $\mathrm{N}$ & 201 & 201 & 201 & 201 \\
\hline \multirow{5}{*}{$\begin{array}{l}\text { Openness } \\
\text { of the } \\
\text { government }\end{array}$} & Pearson's correlation & $.706 * *$ & 1 & $-.328 * *$ & $.656 * *$ \\
\hline & $\begin{array}{l}\text { Significance } \\
\text { (bilateral) }\end{array}$ & .000 & & .000 & .000 \\
\hline & $\begin{array}{l}\text { Sum of squared and } \\
\text { cross product }\end{array}$ & 219.284 & 295.025 & -116.159 & 234.279 \\
\hline & Covariance & 1.096 & 1.475 & -.581 & 1.171 \\
\hline & $\mathrm{N}$ & 201 & 201 & 201 & 201 \\
\hline \multirow{5}{*}{$\begin{array}{c}\text { Social justice } \\
\text { (Engel's } \\
\text { coefficient) }\end{array}$} & Pearson's correlation & $-.402 * *$ & $-.328 * *$ & 1 & $-.600 * *$ \\
\hline & $\begin{array}{c}\text { Significance } \\
\text { (bilateral) }\end{array}$ & .000 & .000 & & .000 \\
\hline & $\begin{array}{c}\text { Sum of squared and } \\
\text { cross product }\end{array}$ & -150.015 & -116.159 & 426.219 & -257.383 \\
\hline & Covariance & -.750 & -.581 & 2.131 & -1.287 \\
\hline & $\mathrm{N}$ & 201 & 201 & 201 & 201 \\
\hline \multirow{5}{*}{$\begin{array}{l}\text { Personal } \\
\text { understanding } \\
\text { of the tax law }\end{array}$} & Pearson's correlation & $.662 * *$ & $.656 * *$ & $-600 * *$ & 1 \\
\hline & $\begin{array}{l}\text { Significance } \\
\text { (bilateral) }\end{array}$ & .000 & .000 & .000 & \\
\hline & $\begin{array}{c}\text { Sum of squared and } \\
\text { cross product }\end{array}$ & 248.776 & 234.279 & -257.383 & 431.920 \\
\hline & Covariance & 1.244 & 1.171 & -1.287 & 2.160 \\
\hline & $\mathrm{N}$ & 201 & 201 & 201 & 201 \\
\hline
\end{tabular}

Note: $* *$ was significantly correlated at .01 level (bilateral)

Correlation analysis would show the correlation between variables. However, to indicate the presence of any causal relationship between variables, it would require regression analysis to estimate the partial regression coefficient of each regressive element. Therefore, the regression analysis is shown in the formula below:

$\mathrm{TC}=\mathrm{a}+\mathrm{b} \times \mathrm{GAO}+\mathrm{c} \times \mathrm{SJ}+\mathrm{d} \times \mathrm{IT}+\mathrm{U}$

TC: tax compliance; GAO: government affairs openness; SJ: social justice; IT: individual taxation

Since there are three numbers in the formula, the multiple determination coefficient $\mathrm{R}^{2}$ and the overall significance of the multiple regression analysis can be determined via the $\mathrm{F}$ test and $\mathrm{T}$ test. $\mathrm{R}^{2}$ would indicate 
the interpretation of the independent variable on the dependent variable which usually shows the value between 0 and 1 whereby the greater the numerical fitting, the better. Value of $F$ below 0.05 would indicate an obvious regression line relationship. For multiple linear regression, $\mathrm{F}$ verification is usually used to test whether a single variable can be excluded from the model. Finally, the T test can be used to verify different levels of contribution of the independent variable to the regression which is simply the degree of regression coefficient. The greater it is, the greater the contribution of independent variables to the regression. The regression of standardized variables should also be done. The regression results are as follows:

$$
\begin{aligned}
& \mathrm{TC}=1.037880+0.084037 \times \mathrm{GAO}+0.011152 \times \mathrm{SJ}+0.207508 \times \mathrm{IT} \\
& \mathrm{SE}=(0.074370)(0.005110)(0.001163)(0.036265), \mathrm{R}^{2}=0.376053
\end{aligned}
$$

It can be concluded that the above assumptions have been effectively tested which shows that there was a significant positive relationship between the openness of government affairs, social justice, and taxpayers' understanding of the tax law with their tax compliance.

Therefore, it is plain that there is a significant positive relationship between governance and tax compliance of taxpayers.

\begin{tabular}{|c|c|c|c|c|}
\hline \multicolumn{5}{|l|}{ Dependent variable, TC } \\
\hline \multicolumn{5}{|l|}{ Method: Least Squares } \\
\hline \multicolumn{5}{|l|}{ Sample: 1 - 201} \\
\hline \multicolumn{5}{|l|}{ Included observations: 201} \\
\hline & Coefficient & Standard error & t statistic & Prob. \\
\hline TC & 1.036880 & 0.072370 & 13.95463 & 0.0000 \\
\hline GAO & 0.084137 & 0.005120 & 16.46509 & 0.0000 \\
\hline SJ & 0.011153 & 0.001162 & 9.592954 & 0.0000 \\
\hline IT & 0.207608 & 0.036365 & 5.721953 & 0.0000 \\
\hline R-squared & 0.376053 & Mean dependent variable & 2.342416 & \\
\hline Adjusted R-squared & 0.373133 & S.D. dependent variable & 0.586356 & \\
\hline S.E. of regression & 0.464247 & Akaike info criterion & 1.308614 & \\
\hline Sum of squared residuals & 127.3030 & Schwarz criterion & 1.336645 & \\
\hline Log likelihood & -567.4018 & Hannan-Quinn criterion & 1.319136 & \\
\hline F-statistic & 128.7771 & Durbin-Watson statistic & 1.977004 & \\
\hline Prob. (F-statistic) & 0.000000 & & & \\
\hline
\end{tabular}

Table 3. Regression analysis on the influence of government governance on taxpayers' tax compliance

\section{Conclusion and Suggestions}

After collecting and summarizing relevant data, the study adopted empirical research methods to prove certain aspects. First, there was a significant positive correlation between the openness of government affairs and taxpayers' tax compliance. Secondly, social justice had a significant positive correlation with tax compliance of taxpayers. Thirdly, there was also a significant positive correlation between the personal understanding of the tax law and the taxpayers' tax compliance. The three aspects which were used to measure government governance were all significantly positively correlated with taxpayers' tax compliance. Hence, concluding that the government governance is significantly positively correlated with the tax compliance of taxpayers.

The concept of macro-governance should be established in the active transformation of the governance concept. In addition to that, a good governance system should be vigorously built, and the institutional 
dividends of governance should be released. At the same time, the concept of government governance should be deeply rooted as daily norms among government staffs to create a bright and service-oriented government while transforming the governance concept. The public should also actively participate in discussing state affairs which is a relatively important aspect to promote efficient interactions between the government and citizens as well as the continuous improvement in the quality of government governance.

With the development of digital economy, it is necessary to transform the government's governance capacity system. At present, the system in China does not meet the needs of the current social development which affects the development of government governance. A few suggestions are made to improve the government's governance ability. First, citizens should be allowed to establish the concept of modern government governance. Second, the development of the e-government platform system should be vigorously emphasized by allowing both, online and offline participation in government governance. Third, legal and institutional guarantees for government governance should be provided, and lastly, government departments should be simple, efficient, lean, and promising.

\section{Disclosure statement}

The author declares no conflict of interest.

\section{References}

[1] Torgler C, Demir IC, Macintyre A, et al., 2008, Causes and consequences of tax morale: an empirical investigation. Economic Analysis \& Policy, 38(2).

[2] Grabowski P, Self S, Staple food price instability and structural change: Indonesian experience. Journal of Asian Economics.

[3] Edirisinghe JC, Smallholder farmers' household wealth and livelihood choices in developing countries: a Sri Lankan case study. Economic Analysis and Policy.

[4] Wang W, 2009, Tax compliance: a study from reason to reality. Huazhong University of Science and Technology.

[5] Yao Y, 2011, Macro perspective of tax compliance decision-making research. Jinan university.

[6] Zhang W, Wang S, 2013, Poverty alleviation policy, income distribution and poverty alleviation in China's rural areas. Issues in Agricultural Economy, 34(02): 66-75, 111. 